\title{
Management Styles and Organisational Effectiveness in Vietnam: A Comparison in Terms of Management Practices between State-owned and Foreign Enterprises
}

\author{
Nhu-Ty Nguyen ${ }^{1}$, Thanh-Tuyen $\operatorname{Tran}^{1} \&$ Chia-Nan Wang ${ }^{2}$ \\ ${ }^{1}$ Lac Hong University, Bien Hoa city, Dong Nai, Vietnam \\ 2 Department of Industrial Engineering and Management, National Kaohsiung University of Applied Sciences, \\ Kaohsiung, Taiwan \\ Correspondence: Nhu-Ty Nguyen, International Relations Office - Lac Hong University, Bien Hoa city, Dong Nai, \\ Vietnam. E-mail: nhutynguyen@gmail.com
}

Received: October 14, 2014

Accepted: November 13, 2014

Online Published: January 4, 2015

doi:10.5430/rwe.v6n1p85

URL: http://dx.doi.org/10.5430/rwe.v6n1p85

\begin{abstract}
Human capital initiatives play a vital role in resolving the most pressing business challenges. The effective management of human poses new challenges in the organization for leadership and managerial capabilities. The current study aims to analyze the factors that are closely associated with employee satisfaction in both Vietnamese state-owned enterprise and foreign-owned enterprise in order to understand the difference of management practices. The response was taken from a sample of 250 respondents in either two types of business and the data are carried out by using multiple statistical analyses, including exploratory factor analysis, reliability test, mean point value, and multiple linear regressions. The results indicate that for the state-owned enterprise, recruitment process is the most important factor that helps to improve the satisfaction of employee. Besides, for the foreign-owned enterprise, as the results of the current study, performance appraisal process is the main point to solve employee's problems. The findings also provide useful implications for managers in terms of improving human capital quality, and stabilizing the labor resources and reducing the turnover rate for both state-owned enterprise and foreign-owned enterprises.
\end{abstract}

Keywords: enterprises, job satisfaction, asset, performance, human, foreign, human capital

\section{Introduction}

Human resources are the set of individuals who make up the workforce of an organization, business sector, or economy (Cascio and McEvoy, 1992). Human resource management is not only as simple as completing well all of the administrative procedures related to human, but it is also considered as business development strategy during this competitive and integrated period. In order to create as much profit as possible for the business, entrepreneurs should consider employee as the most precious asset of the business and make them feel satisfied in their working environment.

From the corporate objective, employees have been traditionally viewed as assets to the enterprise, whose value is enhanced by further learning and development, referred to as human resource development (Wright et al., 2001). Organizations will engage in a broad range of human resource management practices to capitalize on those assets. Besides, employee satisfaction is essential to the success of any business. A high rate of employee contentedness is directly related to a lower turnover rate. Thus, keeping employees' satisfied with their careers should be a major priority for every employer. There are numerous reasons why employees can become stressed and dissatisfied with the organization. Some can be listed as lack of communication within the company, lack of recognition, or limited opportunity for growth. Management should actively seek to improve these factors if they hope to lower their turnover rate. Even in an economic downturn, turnover is an expense best avoided.

Over the last three decades, Vietnam has gained miraculous economic achievements with an attractive foreign investment policy and commitment to a liberalized economy (Tsang et al., 2004). Foreign investors who have been flocking to Vietnam since the early 1990s, with a new peak of FDI inflow in 2004 are seeking business opportunities in both the domestic market of over 80 million potential consumers and in low-cost production sites (Edgington and Hayter, 2001). Also all through the 1990s and up until today, investors from the neighboring countries such as Taiwan, 
Korea, and Japan have been the number one investors in Vietnam. For this situation, it has emerged a competitive between foreign investors and domestic entrepreneurs in which they are making a lot of efforts with a broad range of strategy to attractive talents.

In the context of Vietnamese economies, human capital can be considered as one of the most important asset of the business, so both Vietnamese state-owned enterprises and foreign-owned enterprises are eager for invest their infrastructure and technology and pay attention to attracting the high quality staff and to avoid competition from multinational corporations. This competitive situation creates comparative thoughts among the human capital, who calculate the pros and cons of working in either environment.

This is the fact that many Vietnamese workers are now employed in enterprises which are directly administered by transnational corporations (Nilan, 1999). Although research by some scholars has discussed labor practices, no one has examined and made a comparision between factors affecting employee satisfaction towards both two types of enterprises in Vietnam, i.e. state-owned enterprises and foreign-owned enterprises. In order to understand the relationship of management practices between the Vietnamese employees, state-owned entrepreneurs and foreign investors, this article will focus solely on Vietnam trade unions and medium foreign-owned factories for conducting three main ideas of the research objectives as follows:

(1) The needs and expectations of employees working in an organization for the situation of both Vietnamese state-owned enterprises and foreign-owned enterprises

(2) There exists negative thoughts about state-owned business and why employees leave state enterprises

(3) Advantages and disadvantages when working in foreign-owned enterprises and state-owned enterprises

A major implication for this research is that these findings will able to give better understanding for employee towards both two types of enterprises in Vietnam: state-owned enterprises and foreign-owned enterprises and try to address the factors which will significantly improve the business success. The results of this study can also be used as reference for any entrepreneurs who want to make his human resources become the most profitable and precious asset for the organization.

\section{Literature Review}

\subsection{The Measurement Scales of Job Satisfaction and Loyalty}

\subsubsection{Definitions of Job Satisfaction and Loyalty}

Different authors have different definitions about job satisfaction. One of the most often cited definitions on job satisfaction is one given by Spector (1997). He mentioned that job satisfaction related to the way how people feel about their job and its various aspects. Job satisfaction and job dissatisfaction can appear in any working environment that make workers like or dislike their job.

According to Wang et al. (2014), job satisfaction presents a set of factors that cause a feeling of satisfaction. Kaliski (2007) emphasized job satisfaction focuses on a combination of positive or negative feelings that workers have towards their work. When a worker employed in a business organization, he has the basic needs, desires and experiences that determinate his expectation towards the real awards. Thus if the working conditions and real awards do not meet workers' expectation, it will lead to different feelings of them.

In the study of Janssen and Yperen (2004), job satisfaction is a workers' sense of achievement and success on the job. The author also mentioned that job satisfaction implies doing a job one enjoys, doing it well and being rewarded for one's efforts. The workers are happy and enthusiastic at work place; they are motivated for recognition, promotion, and high salary or bonus that leads to a feeling of fulfilment.

Job satisfaction may refer to the attitude and feelings workers have about their work. Workers who are satisfied with their job have positive and favorable attitudes. Conversely, workers who are dissatisfied with their job have negative and unfavorable attitude (Maslach et al., 2001).

People's levels of degrees of job satisfaction can range from extreme satisfaction to extreme dissatisfaction. People also can have various aspects of their jobs such as the kind of work they do, their co-workers, supervisor or subordinates and their pay (Nemeth et al., 2004). Job satisfaction can be considered as one of the main factors when it comes to efficiency and effectiveness of business organizations (Nguyen et al., 2014).

\subsubsection{Importance of Job Satisfaction and Loyalty}

The importance of job satisfaction contains three importance features. Firstly, business should respect human values and treat workers fairly. Such organizations will be oriented towards treating workers fairly and with respect. High 
levels of job satisfaction may be sign of a good emotional and mental state of employees and demonstrate by good achievement of them at work. Secondly, the function and activity of business may affect to workers' behavior and their level of job satisfaction. From this it can be concluded that job satisfaction will lead to positive behavior and vice versa, dissatisfaction from the work will result in negative behavior of employees. Third, job satisfaction can serve as indicators of the organization's activities. Through the satisfaction of the different assessment of satisfaction in different organizational units can be identified, but in turn can serve as a good indication of which unit changes organizations that can increase the performance to be made (Spector 1997).

\subsection{Proposed Models and Hypotheses}

\subsubsection{The Herzberg's Two- Factors Theory}

The Hezberg's two-factors theory define that there are certain factors in the workplace that cause job satisfaction, while a separate set of factors cause dissatisfaction. Herzberg analyzed the job attitudes of 200 accountant and engineers who were asked to recall when they had felt positive or negative at work and the reason why. From this study, Herzberg suggested a two-step approach to understanding employee motivation and satisfaction (Figure 1)

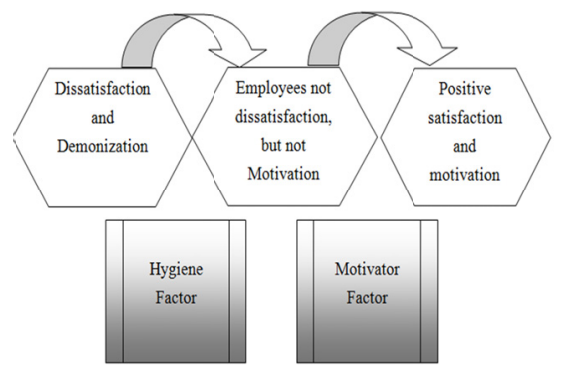

Figure 1. Representation of Herzberg's Two - Factor Theory (DeShields, 2005)

Job satisfaction is under the influence of a series of factors, i.e. the nature of work, salary, advancement opportunities, management, work groups and work conditions. The factors of job satisfaction can cause the phenomenon of job satisfaction (Kumaran, 2008).

In case of job satisfaction, benefits, bureaucracy, supervision, recognition, and fairness in pay are the most important factors, which have significant impact on the overall social economic lives of female labor. The overall impact is defined as the social economic status of the workers, which consist of social status, income .etc (Golbasi et al., 2005). Wang et al. (2014) emphasized the variables related to worker's satisfaction are working environment; current health care facility; and overtime benefits.

\subsubsection{Workplace Environment Characteristics}

Some elements related to workplace environment characteristics may be considered keys affecting employee's engagement, productivity, morale, comfort level etc. both positively and negatively. Although convenient workplace conditions are requirements for improving productivity and quality of outcomes, working conditions in many organizations may present lack of safety, health and comfort issues such as improper lightening and ventilation, excessive noise and emergency excess. People working under inconvenient conditions may end up with low performance and face occupational health diseases causing high absenteeism and turnover (Bockerman and Ilmakunnas, 2009). From a safety perspective, Gyekye and Salminen (2009) indicate that environmental conditions affect employee safety perceptions which impact upon employee commitment.

Hypothesis 1: Workplace environment characteristics have positive effect on laborers' satisfaction.

\subsubsection{Effect of Salary and Remuneration Packages}

Effect of salary and remuneration policy on employees' productivity could be very strong in some organizations. (Sekar et al., 2001) stated that good compensation for employees will be able to stimulate the emergence of fresh ideas and employees' innovation. In a similar study, Gyekye and Salminen (2009) also found that the existence of a good salary of employees will make the health of employees also good. With the maintenance of health, the employee will get maximum performance opportunities. The number of working hours or employee present hours is able to obtain a maximum work performance. As a result, the planning process can be obtained with good production.

They also noted that low compensation toward employees will trigger the employee to try to get their own business or side job. With the side business, it will disrupt the quality of employees' work and concentration. Low 
concentrations of certain employees have a negative impact on quality and quality of production of goods in the company. From these facts, it is clear that the influence of compensation on employee productivity is very strong. If it given more reasonable compensation to employees, the higher the productivity of employees. Conversely, if it given lower compensation for employees, the lower the productivity of the employee (Coomber and Louise, 2007). Many executives are under the mistaken impression that the level of employee performance on the job and their loyalty is proportional to the size of the employee's compensation package. Although compensation package as well as promotion and awards are among the extrinsic motivation tools (Bockerman and Ilmakunnas, 2009) they has a limited short term effect on employees' performance.

Hypothesis 2: Salary and remuneration policy has positive effect on laborers' satisfaction.

\subsubsection{Supervisor Support}

Supervisor support is crucial for employees to complete the job. Supervisors' interpersonal role is important to encourage positive relations and increase self-confidence of the employee. Skilled and respected people are available to employees to help them to perform better in their current role and to assist them develop further into a future role. Haynes (2008) defines the situation as mentoring/coaching. Time and material resources should be available to employees, enabling them to perform to the best of their ability.

Hypothesis 3: Supervisor support has positive effect on laborers' satisfaction.

\subsubsection{Performance Appraisal Process}

In the conventional performance appraisal or review process, the manager annually writes his opinions of the performance of a reporting staff member on a document supplied by the human resource department. In some organizations, the staff member is asked to fill out a self-review to share with the supervisor. Most of the time, the appraisal reflects what the manager can remember; this is usually the most recent events.

Many managers are uncomfortable in the role of judge, so uncomfortable, in fact, that performance appraisals are often months overdue. The human resource professional has his important roles to develop the form and maintain an employee official file, notify supervisors of due dates.

If performance appraisal or review process does not work, the employee may feel his manager doesn't care about him enough to facilitate his annual raise. Disagreement about contribution and performance ratings can create a conflict ridden situation that festers for months. Most managers avoid conflict that will undermine work place harmony. In today's team-oriented work environment, it is also difficult to ask people who work as colleagues, and sometimes even friends, to take on the role of judge and defendant.

Hypothesis 4: Performance appraisal process has positive effect on laborers' satisfaction.

\subsubsection{Recruitment Process}

A recruitment process is an organization-specific model of how the sourcing of new employees is undertaken. Typically the ownership of the recruitment process resides within the Human Resources function, although again this may differ depending on the specific organizational structure.

According to Randolph (2004), recruitment is a process to discover the sources of manpower to meet the requirements of the staffing schedule and to employ effective measures for attracting that manpower in adequate numbers to facilitate effective selection of an efficient working force.

He also emphasized some factors effecting recruitment: (1) Size if the organization; (2) The employment condition; (3) The effect of past recruiting efforts; (4) Working condition and salary; (5) Rate of growth of organization; (6) The future expansion plans; (7) Cultural, economic and legal factors; (8) Company’s image; (9) Recruitment policy.

Hypothesis 5: Recruitment process has positive effect on laborers' satisfaction.

\subsubsection{Professional Development and Training}

In workplaces, professional development and training refers to the acquisition of skills and knowledge, both for personal development and for career advancement. Professional development encompasses all types of facilitated learning opportunities, ranging from college degrees to formal coursework conferences and informal learning opportunities situated in practice. There are a variety of approaches to professional development, including consultation, coaching, and communities of practice, lesson study, mentoring, reflective supervision and technical assistance.

Hypothesis 6: Professional development and training has positive effect on laborers' satisfaction. 


\subsection{Vietnamese State-owned Enterprises}

Vietnam's roughly 1,000 state firms take up 45 percent of its total investments and assets, and 27 percent of bank loans, but yield less than 17 percent of its industrial output and provide jobs to only 1 percent of the workforce, according to Nguyen Dinh Cung, director of the Central Institute for Economic Management. The establishment of groups and state owned corporations according to decisions of Prime Minister. Vietnamese state-owned enterprises play a key pillar of Vietnam's economy to help Vietnam primarily become an industrial country by 2020 as well as a tool to operate the economy.

In the context of Vietnamese economies, these enterprises need more investment of infrastructure and technology and pay attention to improving the quality staff and managers to avoid competition from multinational corporations. In general, Vietnamese state-owned enterprises cover most of business areas in the economy, such as (1) Electricity; (2) Cement; (3) Construction; (4) Power; (5) Petrol; (6)Telecommunication; (7) Ship Building; (8) Coal and Mineral, etc.

\subsection{Foreign-owned Enterprises}

An investment made by a foreign-owned company or entity based in one country, into a company or entity based in another country (Birkinshaw\& Hood, 1998). Open economies with skilled workforces and good growth prospects tend to attract larger amounts of foreign direct investment than closed, highly regulated economies. Foreign owner refers to the complete or majority control of a business or resource in a country by individuals who are not citizens of that country, or by companies whose headquarters are not in that country.

The investing company may make its overseas investment in a number of ways - either by setting up a subsidiary or associate company in the foreign country, by acquiring shares of an overseas company, or through a merger or joint venture.

\section{Methodology}

\subsection{Research Design}

A questionnaire was developed as an instrument of data collection and designed by the researcher after objective criticisms and suggestions from experts. It was delivered to respondents who are currently working at both Vietnamese state-owned enterprises and foreign-owned enterprises.

\subsection{Measurement Instrument}

The questionnaire composed of three sections: (1) Section one collects the demographic information; (2) Section two collects the response on the six sub-scales of employee's satisfaction (workplace environment characteristics, salary and remuneration policy, supervisor support, performance appraisal process, recruitment process and professional development and training); (3) Section three contains additional questions about overall satisfaction of customer.

The five-point Likert scale- These items were in the form of five-point Likert scale. Options were ordered as; "Strongly dissatisfied", "dissatisfied", "Undecided", "satisfied" and "Strongly satisfied". The answers were ordered from "Strongly dissatisfied" to "Strongly satisfied" by grading them from 1 to 5 .

\subsection{Data Collection}

Questionnaire was designed and presented in May, 2014. Each questionnaire has 30 variables in total, so the necessary sample size is $n \geq 30 \times 5=150$. However, the response was taken from a sample of 250 respondents. The data was collected during a period of five weeks, while personally visiting both Vietnamese-owned enterprises and foreign-owned enterprises to asking the employees to either tell or write their replies in response to 250 samples developed by 2 groups. For the first group of respondents who are working at Vietnamese-owned enterprises, there are 183 samples which are good to be analyzed (67 questionnaires were discarded). The response rate is represented at $73.2 \%$.

For the second group of respondents who are working at foreign-owned enterprises, there are 230 samples which are good to be analyzed ( 20 questionnaires were discarded). The response rate is represented at $92 \%$.

\subsection{Method of Data Analysis}

Descriptive statistic is defined as a set of brief descriptive coefficients that summarizes a given data set, which can either be a representation of the entire population or a sample. The measures used to describe the data set are measures of central tendency and measures of variability or dispersion. Measures of central tendency include the mean, median and mode, while measures of variability include the standard deviation (or variance), the minimum and maximum variables. Descriptive statistics provides a useful description of the basic features of a collection of the 
data in a study. Together with simple graphics analysis, they form the basis of virtually every quantitative analysis of data. In this study, the researcher uses percentage and frequency to present the demographic characteristic of respondents.

The validity of a questionnaire relies first and foremost on reliability. If the questionnaire cannot be shown to be reliable, there is no discussion of validity. Validity refers to whether the questionnaire or survey measures what it intends to measure. The overriding principle of validity is that it focuses on how a questionnaire or assessment process is used. Reliability is a characteristic of the instrument itself, but validity comes from the way the instrument is employed. Content validity referred to whether the instrument can cover items that purpose to cover. At first, recommends that literature had to be reviewed to get the theoretical knowledge about the content or definitions of concepts that are used before designing the instrument for the particular study. Next, content validity for the survey instrument was received advices from experts for advices because their review and comments help to eliminate ambiguities in the items.

Reliability indicates degrees of consistency between multiple measurements of a variable. Firstly, we consider consistency of the entire scale, which Cronbach's alpha being the most widely used measure. The lower limit for Cronbach's alpha is .70, although it may decrease to .60 in exploratory research. The present study adopts Peterson (1994) suggestions with the value 0.6 deemed the lower limit of acceptability. Next, to measure item reliability, we regard on the item-to-total correlation (the correlation of the item to the summated scale score). It is suggested that the item-to-total correlations should exceed 0.3.

In multivariate statistics, exploratory factor analysis (EFA) is a statistical method used to uncover the underlying structure of a relatively large set of variables. EFA is a technique within factor analysis whose overarching goal is to identify the underlying relationships between measured variables. It is commonly used by researchers when developing a scale (a scale is a collection of questions used to measure a particular research topic) and serves to identify a set of latent constructs underlying a battery of measured variables. It should be used when the researcher has no a priori hypothesis about factors or patterns of measured variables. Measured variables are any one of several attributes of people that may be observed and measured. An example of a measured variable would be one item on a scale. Researchers must carefully consider the number of measured variables to include in the analysis. EFA procedures are more accurate when each factor is represented by multiple measured variables in the analysis. There should be at least 3 to 5 measured variables per factor.

Our study applied exploratory factor analysis as a highly useful and powerful multivariate statistical technique for effectively extracting information from large bodies of interrelated data. When variables are correlated, we manage these variables by grouping highly correlated variables together, labeling or naming the groups.

Multiple regression analysis is a powerful technique used for predicting the unknown value of a variable from the known value of two or more variables- also called the predictors. The objective of multiple regression analysis is to use the independent variables whose values are known to predict the single dependent value selected by the researcher. More precisely, multiple regression analysis helps us to predict the value of $\mathrm{Y}$ for given values of X1, $\mathrm{X} 2, \ldots, \mathrm{Xk}$.

By multiple regressions, we mean models with just one dependent and two or more independent (exploratory) variables. The variable whose value is to be predicted is known as the dependent variable and the ones whose known values are used for prediction are known independent (exploratory) variables.

In general, the multiple regression equation of $\mathrm{Y}$ on $\mathrm{X} 1, \mathrm{X} 2, \ldots, \mathrm{Xk}$ is given by:

$$
\mathrm{Y}=\mathrm{b} 0+\mathrm{b} 1 \mathrm{X} 1+\mathrm{b} 2 \mathrm{X} 2+\ldots \ldots \ldots \ldots \ldots \ldots \ldots+\mathrm{bk} \mathrm{Xk}
$$

Here $b 0$ is the intercept and $b 1, b 2, b 3, \ldots, b k$ are analogous to the slope in linear regression equation and are also called regression coefficients. They can be interpreted the same way as slope. Thus if $\mathrm{bi}=2.5$, it would indicates that $\mathrm{Y}$ will increase by 2.5 units if $\mathrm{Xi}$ increased by 1 unit.

Besides, the standardized regression coefficients $(\beta)$ reflect the relative impact on dependent variable of a change in one standard deviation in either variable. Now that we have a unit of measurement, we can determine which variable has the most impact.

Once a multiple regression equation has been constructed, one can check how good it is (in terms of predictive ability) by examining the coefficient of determination $\left(R^{2}\right)$. $R^{2}$ always lies between 0 and 1 . The closer $R^{2}$ is to 1 , the better is the model and its prediction. 
The correlation coefficient, denoted by $\mathrm{r}$, is a measure of the strength of the linear relationship between two variables. The correlation coefficient takes on values ranging between +1 and -1 . If correlation coefficient equal to 0 indicates no linear relationship, +1 indicates a perfect positive linear relationship: as one variable increases in its values, -1 indicates a perfect negative linear relationship: as one variable increases in its values. In details, if correlation coefficient values between 0 and 0.3 ( 0 and -0.3$)$ indicate a weak positive (negative) linear relationship via a shaky linear rule, between 0.3 and $0.7(0.3$ and -0.7$)$ indicate a moderate positive (negative) linear relationship via a fuzzy-firm linear rule, between 0.7 and 1.0 (-0.7 and -1.0) indicate a strong positive (negative) linear relationship via a firm linear rule.

\section{Data Analysis and Results}

\subsection{A Description of the Sample}

A description of the sample is as follows:

Table 1. Statistics of the sampled respondents' characteristics

\begin{tabular}{|c|c|c|c|c|c|}
\hline & Category & $\begin{array}{l}\text { Frequency } 1 \\
\text { (Vietnamese } \\
\text { state-owned } \\
\text { companies) }\end{array}$ & $\begin{array}{c}\text { Frequency2 } \\
\text { (Foreign } \\
\text { companies) }\end{array}$ & $\begin{array}{l}\text { Percentage1 } \\
\text { (Vietnamese } \\
\text { state-owned } \\
\text { companies) }\end{array}$ & $\begin{array}{c}\text { Percentage2 } \\
\text { (Foreign } \\
\text { companies) }\end{array}$ \\
\hline \multirow[t]{2}{*}{ Gender } & Female & 111 & 123 & $60.7 \%$ & $53.5 \%$ \\
\hline & Male & 72 & 107 & $39.3 \%$ & $46.5 \%$ \\
\hline \multirow[t]{5}{*}{ Department } & Financial Planning & 37 & 34 & $20.2 \%$ & $14.9 \%$ \\
\hline & Trade in Goods and Services & 65 & 45 & $35.5 \%$ & $19.6 \%$ \\
\hline & Computer and Information & 22 & 25 & $12.0 \%$ & $10.9 \%$ \\
\hline & Research \& Development & 8 & 26 & $4.4 \%$ & $11.3 \%$ \\
\hline & Finance and Accounting & 51 & 100 & $27.9 \%$ & $43.4 \%$ \\
\hline \multirow[t]{4}{*}{ Education } & Less than Bachelor's Degree & 6 & 7 & $3.3 \%$ & $3.0 \%$ \\
\hline & Bachelor's & 16 & 25 & $8.7 \%$ & $10.8 \%$ \\
\hline & Master's & 142 & 135 & $77.6 \%$ & $58.7 \%$ \\
\hline & Ph.D. & 19 & 63 & $10.4 \%$ & $27.4 \%$ \\
\hline \multirow[t]{4}{*}{ Age } & $<30$ & 93 & 96 & $50.8 \%$ & $41.7 \%$ \\
\hline & $31 \sim 40$ & 65 & 87 & $35.5 \%$ & $37.8 \%$ \\
\hline & $41 \sim 50$ & 23 & 45 & $12.6 \%$ & $19.6 \%$ \\
\hline & $51 \sim 60$ & 2 & 2 & $1.1 \%$ & $0.87 \%$ \\
\hline \multirow[t]{4}{*}{ Income } & Less than $200 \$$ & 12 & 10 & $6.6 \%$ & $4.35 \%$ \\
\hline & $200 \$ \sim 400 \$$ & 96 & 67 & $52.5 \%$ & $29.1 \%$ \\
\hline & $400 \$-500 \$$ & 34 & 98 & $18.6 \%$ & $42.6 \%$ \\
\hline & Above $500 \$$ & 41 & 55 & $22.5 \%$ & $23.9 \%$ \\
\hline Total & & 183 & 230 & $100 \%$ & $100 \%$ \\
\hline
\end{tabular}

\subsection{Cronbach's Alpha for Measurement Scale 1 - (State-owned Enterprises)}

Table 2 shows Cronbach's alpha for the variables related to (1) workplace environment characteristics, (2) salary and remuneration policy, (3)supervisor support, (4) performance appraisal process, (5) recruitment process and (6) professional development and training were $0.856,0.859,0.882,0.840,0.829$, and 0.876 respectively indicating acceptable internal consistency reliability. No item of this subscale was removed based on the item total correlation (> $0.30)$. 
Table 2. Cronbach's Alpha for available variables

\begin{tabular}{|c|c|c|c|c|c|c|}
\hline Measurement Scale & $\begin{array}{l}\text { Cronbach's } \\
\text { alpha } 1\end{array}$ & $\begin{array}{c}\text { Cronbach's } \\
\text { alpha } 2 \\
\end{array}$ & \multicolumn{2}{|c|}{ Corrected Item-Total Correlation 1} & \multicolumn{2}{|c|}{ Corrected Item-Total Correlation 2} \\
\hline \multirow{4}{*}{$\begin{array}{c}\text { Workplace } \\
\text { Environment } \\
\text { Characteristics }\end{array}$} & \multirow{4}{*}{0.856} & \multirow{4}{*}{.876} & $\mathrm{X} 1$ & .724 & Y1 & .760 \\
\hline & & & $\mathrm{X} 3$ & .679 & Y3 & .652 \\
\hline & & & $\mathrm{X} 4$ & .736 & Y4 & .706 \\
\hline & & & $\mathrm{X} 5$ & .745 & Y5 & .649 \\
\hline \multirow{5}{*}{$\begin{array}{c}\text { Salary and } \\
\text { Remuneration Policy }\end{array}$} & \multirow{5}{*}{0.859} & \multirow{5}{*}{.713} & $\mathrm{X} 6$ & .684 & Y6 & .821 \\
\hline & & & $\mathrm{X} 7$ & .785 & Y7 & .691 \\
\hline & & & $\mathrm{X} 8$ & .744 & Y8 & .821 \\
\hline & & & X9 & .606 & Y9 & .691 \\
\hline & & & $\mathrm{X} 10$ & .684 & Y10 & 663 \\
\hline \multirow{4}{*}{ Supervisor Support } & \multirow{4}{*}{0.882} & \multirow{4}{*}{.710} & $\mathrm{X} 11$ & .674 & Y11 & 6.470 \\
\hline & & & $\mathrm{X} 13$ & .719 & Y13 & 6.974 \\
\hline & & & $\mathrm{X} 14$ & .738 & Y14 & 6.535 \\
\hline & & & X15 & .683 & Y15 & 6.246 \\
\hline \multirow{5}{*}{$\begin{array}{c}\text { Performance } \\
\text { Appraisal Process }\end{array}$} & \multirow{5}{*}{0.840} & \multirow{5}{*}{.808} & $\mathrm{X} 16$ & .724 & Y16 & .644 \\
\hline & & & $\mathrm{X} 17$ & .719 & Y17 & .653 \\
\hline & & & $\mathrm{X} 18$ & .670 & Y18 & .662 \\
\hline & & & X19 & .633 & Y19 & .654 \\
\hline & & & X20 & 699 & Y20 & 687 \\
\hline \multirow{4}{*}{ Recruitment Process } & \multirow{4}{*}{0.829} & \multirow{4}{*}{.767} & $\mathrm{X} 21$ & .696 & Y21 & .568 \\
\hline & & & $\mathrm{X} 22$ & .612 & Y22 & .644 \\
\hline & & & $\mathrm{X} 23$ & .760 & Y23 & .544 \\
\hline & & & $\mathrm{X} 24$ & .567 & Y24 & .510 \\
\hline \multirow{5}{*}{$\begin{array}{c}\text { Professional } \\
\text { Development and } \\
\text { Training }\end{array}$} & \multirow{5}{*}{0.876} & \multirow{5}{*}{0.903} & $\mathrm{X} 26$ & .722 & Y26 & .841 \\
\hline & & & $\mathrm{X} 27$ & .706 & Y27 & .801 \\
\hline & & & $\mathrm{X} 28$ & .671 & Y28 & .777 \\
\hline & & & $\mathrm{X} 29$ & .712 & Y29 & .745 \\
\hline & & & $\mathrm{X} 30$ & .712 & Y30 & .878 \\
\hline
\end{tabular}

Note: Cronbach's alpha 1: State-owned Enterprises; Cronbach's alpha 2: Foreign -owned Enterprises

Corrected Item-Total Correlation 1: State-owned Enterprises; Corrected Item-Total Correlation 2: Foreign -owned Enterprises

\subsection{Exploratory Factor Analysis}

The measurement scale for employees' satisfaction including 6 components: (1) workplace environment characteristics, (2) salary and remuneration policy, (3)supervisor support, (4) performance appraisal process, (5) recruitment process and (6) professional development and training is analyzed with EFA approach.

As shown in Table 3, the KMO is 0.884 and the significance is lower than 0.01 . Then we concluded that the subject questionnaire item is suitable for factor analysis.

Table 3. KMO and Bartlett's Test

\begin{tabular}{crrrrr}
\hline \multicolumn{2}{c}{ State-owned Enterprises } & \multicolumn{3}{c}{ Foreign-owned Enterprises } \\
\hline \multicolumn{2}{c}{ Kaiser-Meyer-Olkin Measure of Sampling Adequacy. } & \multicolumn{1}{c}{0.884} & Kaiser-Meyer-Olkin Measure of Sampling Adequacy. & 0.812 \\
\hline \multirow{2}{*}{ Bartlett's Test of } & Approx. Chi-Square & 3154.056 & Bartlett's Test of & Approx. Chi-Square & Df \\
Sphericity & df & 231 & Sphericity & Sig. & $2.037 \mathrm{E3}$ \\
& Sig. & 0.000 & & 0.000 \\
\hline
\end{tabular}


The eigenvalues for the first 6 components are all greater than 1 and these factors account for more than $70 \%$ of the total variance. This suggests that the scale items are one-dimensional. Exploratory Factor Analysis (EFA) result is shown as Table 4:

Table 4. Rotated component matrix

\begin{tabular}{|c|c|c|c|c|c|c|c|c|c|c|c|c|c|}
\hline \multicolumn{7}{|c|}{ State-owned Enterprises } & \multicolumn{7}{|c|}{ Foreign-owned Enterprises } \\
\hline Component & 1 & 2 & 3 & 4 & 5 & 6 & Component & 1 & 2 & 3 & 4 & 5 & 6 \\
\hline $\mathrm{X} 1$ & .854 & -- & -- & -- & -- & -- & Y1 & .854 & -- & -- & -- & -- & -- \\
\hline $\mathrm{X} 2$ & .799 & -- & -- & -- & -- & -- & Y2 & .799 & -- & -- & -- & -- & -- \\
\hline $\mathrm{X} 3$ & .699 & -- & -- & -- & -- & -- & Y3 & .699 & -- & -- & -- & -- & -- \\
\hline $\mathrm{X} 4$ & .690 & -- & -- & -- & -- & -- & Y4 & .690 & -- & -- & -- & -- & -- \\
\hline $\mathrm{X} 5$ & .578 & & & & & & Y5 & .878 & & & & & \\
\hline $\mathrm{X} 7$ & -- & .884 & -- & -- & -- & -- & Y10 & -- & .758 & -- & -- & -- & -- \\
\hline $\mathrm{X} 8$ & -- & .887 & -- & -- & -- & -- & Y7 & -- & .851 & -- & -- & -- & -- \\
\hline X9 & -- & .851 & -- & -- & -- & -- & Y8 & -- & .768 & -- & -- & -- & -- \\
\hline X10 & -- & .768 & -- & -- & -- & -- & Y9 & -- & .987 & -- & -- & -- & -- \\
\hline X11 & -- & -- & .876 & -- & -- & -- & Y11 & -- & -- & .773 & -- & -- & -- \\
\hline $\mathrm{X} 12$ & -- & -- & .820 & -- & -- & -- & Y12 & -- & -- & .820 & -- & -- & -- \\
\hline X13 & -- & -- & .740 & -- & -- & -- & Y13 & -- & -- & .740 & -- & -- & -- \\
\hline X14 & -- & -- & .766 & -- & -- & -- & Y14 & -- & -- & .854 & -- & -- & -- \\
\hline $\mathrm{X} 17$ & -- & -- & -- & .784 & -- & -- & Y17 & -- & -- & -- & .766 & -- & -- \\
\hline $\mathrm{X} 18$ & -- & -- & -- & .663 & -- & -- & Y18 & -- & -- & -- & .784 & -- & -- \\
\hline X19 & -- & -- & -- & .608 & -- & -- & Y19 & -- & -- & -- & .837 & -- & -- \\
\hline $\mathrm{X} 20$ & -- & -- & -- & .741 & -- & -- & Y20 & -- & -- & -- & .965 & -- & -- \\
\hline X21 & -- & -- & -- & -- & .789 & -- & Y21 & -- & -- & -- & -- & .663 & -- \\
\hline X23 & -- & -- & -- & -- & .797 & -- & Y23 & -- & -- & -- & -- & .608 & -- \\
\hline X24 & -- & -- & -- & -- & .650 & -- & Y24 & -- & -- & -- & -- & .741 & -- \\
\hline X25 & -- & -- & -- & -- & .877 & -- & Y25 & -- & -- & -- & -- & .789 & -- \\
\hline $\mathrm{X} 26$ & -- & -- & -- & -- & -- & .777 & Y26 & -- & -- & -- & -- & -- & .797 \\
\hline $\mathrm{X} 27$ & -- & -- & -- & -- & -- & .787 & Y27 & -- & -- & -- & -- & -- & .650 \\
\hline $\mathrm{X} 28$ & -- & -- & -- & -- & -- & .987 & Y28 & -- & -- & -- & -- & -- & .600 \\
\hline X29 & -- & -- & -- & -- & -- & .666 & Y29 & -- & -- & -- & -- & -- & .578 \\
\hline X30 & -- & -- & -- & -- & -- & .766 & Y30 & -- & -- & -- & -- & -- & .789 \\
\hline
\end{tabular}

\subsection{Mean Value Comparison}

The mean values of each item are calculated under the reliability analysis and briefly demonstrated in Table 5 .

Table 5. Summary statistic means value of six factors in the measurement scale

\begin{tabular}{lcc}
\hline Items & State-owned & $\begin{array}{c}\text { Foreign-owned } \\
\text { Enterprises }\end{array}$ \\
\hline Workplace Environment Characteristics & 3.00 \\
I am satisfied with the facilities at working place. & 3.52 & 3.69 \\
There is a balance between my work and my personal life. & 3.44 & 2.81 \\
I am satisfied with temporature, light and noise at working place. & 3.87 & 3.76 \\
I feel satisfied with the workload and the nature of work. & 3.36 & 3.14 \\
I am satisfied with the company's first aid facilities. & $\mathbf{3 . 4 3 8}$ & 3.54
\end{tabular}

Salary and Remuneration Policy 


\begin{tabular}{cc}
3.21 & 3.98 \\
4.80 & 3.12 \\
3.25 & 4.74 \\
3.11 & 3.65 \\
\hline $\mathbf{3 . 5 9 2 5}$ & $\mathbf{3 . 8 7 2 5}$
\end{tabular}

\section{Supervisor Support}

Top manager always supports employee.

Top manager encourage cooperation among staff.

\begin{tabular}{ll}
2.65 & 3.56 \\
3.00 & 4.12 \\
3.45 & 3.58 \\
3.12 & 3.99 \\
\hline $\mathbf{3 . 0 5 5}$ & $\mathbf{3 . 8 1 2 5}$
\end{tabular}

\section{Performance Appraisal Process}

Ensures teamwork and co-operation among staff

\begin{tabular}{cc}
3.90 & 3.66 \\
3.10 & 4.00 \\
3.11 & 4.31 \\
3.14 & 4.21 \\
\hline $\mathbf{3 . 3 1 2 5}$ & $\mathbf{4 . 0 4 5}$
\end{tabular}

\section{Recruitment Process}

I got selected through the recruitment process and I was satisfied with the results announced.

\begin{tabular}{ll}
2.78 & 4.25 \\
3.20 & 3.60 \\
3.13 & 4.68 \\
3.10 & 3.88 \\
\hline $\mathbf{3 . 0 5 2 5}$ & $\mathbf{4 . 1 0 2 5}$
\end{tabular}

I was consistently informed of the various interviewing steps through recruitment process.

I was given the results of my interview in a timely manner.

I was treated respectfully and fairly during the recruitment process.

Professional Development and Training

I am satisfied with training courses provided by the company.

\begin{tabular}{ll}
3.25 & 3.77 \\
2.56 & 4.11 \\
3.14 & 4.54 \\
3.65 & 3.77 \\
2.44 & 4.00 \\
\hline $\mathbf{3 . 1 5}$ & $\mathbf{4 . 0 4 7 5}$
\end{tabular}

Training courses are helpful with career growth.

Training courses improve working skills perfectly.

Training courses provided timely and fairly.

4.0475

\subsection{Regression Analysis}

\subsubsection{For State-owned Enterprise}

Table 6 provides the $\mathrm{R}$ and $\mathrm{R}^{2}$ value. The $\mathrm{R}$ value is 0.777 , which represents the simple correlation and, therefore, indicates a high degree of correlation. The $\mathrm{R}^{2}$ value indicates how much of the dependent variable can be explained by the independent variable. In this case, $60.3 \%$ can be explained, which is very large.

Table 6. Model summary

\begin{tabular}{|c|c|c|c|c|c|}
\hline $\begin{array}{l}\overline{0} \\
\frac{0}{2}\end{array}$ & $\mathrm{R}$ & R Square & $\begin{array}{r}\text { Adjusted R } \\
\text { Square }\end{array}$ & Std. Error of the Estimate - & Sig. F Change \\
\hline 1 & $.777^{\mathrm{a}}$ & .603 & .590 & 2.887 & .000 \\
\hline
\end{tabular}

a. Predictors: (Constant), Workplace Environment Characteristics, Salary and Remuneration Policy, Supervisor Support, Performance Appraisal Process, Recruitment Process and Professional Development and Training

b. Dependent Variable: Job satisfaction state-owned company 
Table 7 indicates that the regression model predicts the outcome variable significantly well. $\mathrm{P}<0.0005$ which is less than 0.05 and indicates that, overall, the model applied is significantly good enough in predicting the outcome variable.

Table 7. ANOVA

\begin{tabular}{ccccccc}
\hline & Model & Sum of Squares & df & Mean Square & F & Sig. \\
\hline \multirow{2}{*}{1} & Regression & 2232.042 & 6 & 372.007 & 44.632 & $.000^{\mathrm{a}}$ \\
\cline { 2 - 7 } & Residual & 1466.952 & 176 & 8.335 & & \\
\cline { 2 - 7 } & Total & 3698.995 & 182 & & & \\
\hline
\end{tabular}

a. Predictors: (Constant), Workplace Environment Characteristics, Salary and Remuneration Policy, Supervisor Support, Performance Appraisal Process, Recruitment Process and Professional Development and Training

b. Dependent Variable: Job satisfaction at state-owned company

The regression output, reproduced in Table 8 shows that Workplace Environment Characteristics and Supervisor Support are not significant ( $\mathrm{sig}>5 \%$ ). This variable barely fails to reach significance and drop out of the regression model. Salary and Remuneration Policy, Performance Appraisal Process, Recruitment Process, Professional Development and Training are significant (sig<0.05). The model estimated is as follows:

$$
\mathrm{Y}=6.984-0.274 \mathrm{X}_{1}+0.276 \mathrm{X}_{2}+0.615 \mathrm{X}_{3}+0.334 \mathrm{X}_{4}
$$

Or:

$$
\begin{aligned}
\text { Satisfaction } & =6.984-0.274 \text { Salary and Remuneration Policy }+0.276 \text { Performance Appraisal Process } \\
& +0.615 \text { Recruitment Process }+0.334 \text { Professional Development and Training }
\end{aligned}
$$

From the model, we can conclude that the Recruitment Process $(\beta=0.615)$ is the factor that has most impact on employee satisfaction, and follow by Professional Development and Training $(\beta=0.334)$, Performance Appraisal Process $(\beta=0.276)$.

Salary and Remuneration Policy has opposite effect on employee satisfaction $(\beta=-0.247)$. One of the reasons of this can be assumed as the higher salary employee can gets, the greater responsibility employees have to take.

Table 8. Coefficients

\begin{tabular}{ccccc}
\hline \multirow{2}{*}{ Models } & \multicolumn{2}{c}{ Un-standardized Coefficients } & \multirow{2}{*}{$\mathrm{s}$} & Sig. \\
\cline { 2 - 4 } & $\mathrm{B}$ & $\mathrm{Std}$. Error & & 0.000 \\
\hline Constant & 6.984 & 1.280 & 5.456 & 0.246 \\
\hline Workplace Environment Characteristics & -0.098 & 0.084 & -1.163 & 0.001 \\
\hline Salary and Remuneration Policy & -0.247 & 0.070 & -3.542 & 0.659 \\
\hline Supervisor Support & 0.053 & 0.121 & 0.441 & 0.000 \\
\hline Performance Appraisal Process & 0.276 & 0.076 & 3.634 & 0.000 \\
\hline Recruitment Process & 0.615 & 0.140 & 4.392 & 0.000 \\
\hline Professional Development and Training & 0.334 & 0.070 & 4.783 & \\
\hline
\end{tabular}

\subsubsection{For Foreign-owned Enterprises}

Table 9 provides the $\mathrm{R}$ and $\mathrm{R}^{2}$ value. The $\mathrm{R}$ value is 0.710 , which represents the simple correlation and, therefore, indicates a high degree of correlation. The $\mathrm{R}^{2}$ value indicates how much of the dependent variable can be explained

\begin{tabular}{|c|c|c|c|c|c|}
\hline$\sum_{i}^{\bar{d}}$ & $\mathrm{R}$ & R Square & $\begin{array}{r}\text { Adjusted R } \\
\text { Square }\end{array}$ & Std. Error of the Estimate & Sig. F Change \\
\hline 1 & $.710^{\mathrm{a}}$ & 0.504 & 0.487 & 0.472 & .000 \\
\hline
\end{tabular}
by the independent variable. In this case, $50.4 \%$ can be explained, which is very large.

Table 9. Model summary

a. Predictors: (Constant), Workplace Environment Characteristics, Salary and Remuneration Policy, Supervisor Support, Performance Appraisal Process, Recruitment Process and Professional Development and Training

b. Dependent Variable: Job satisfaction at foreign-owned company 
Table 10 indicates that the regression model predicts the outcome variable significantly well. $\mathrm{P}<0.0005$ which is less than 0.05 and indicates that, overall, the model applied is significantly good enough in predicting the outcome variable.

Table 10. ANOVA

\begin{tabular}{ccccccc}
\hline & Model & Sum of Squares & df & Mean Square & F & Sig. \\
\hline \multirow{2}{*}{1} & Regression & 39.953 & 6 & 6.659 & 29.851 & $\mathbf{. 0 0 0}^{\mathbf{a}}$ \\
\cline { 2 - 7 } & Residual & 39.260 & 176 & .223 & & \\
\cline { 2 - 6 } & Total & 79.213 & 182 & & & \\
\hline
\end{tabular}

a. Predictors: (Constant), Workplace Environment Characteristics, Salary and Remuneration Policy, Supervisor Support, Performance Appraisal Process, Recruitment Process and Professional Development and Training

b. Dependent Variable: Job satisfaction at foreign-owned company

The regression output, reproduced in Table 11 shows that Workplace Environment Characteristics and Supervisor Support, Recruitment Process and Professional Development and Training are not significant (sig >5\%). This variable barely fails to reach significance and drop out of the regression model. Salary and Remuneration Policy, and Performance Appraisal Process is significant (sig<0.05). The model estimated is as follows:

$$
\mathrm{Y}=0.619+0.021 \mathrm{X}_{1}+0.031 \mathrm{X}_{2}+0.031 \mathrm{X}_{3}+0.053 \mathrm{X}_{4}-0.009 \mathrm{X}_{5}+0.014 \mathrm{X}_{6}
$$

From the model, we can conclude that the Performance Appraisal Process $(\beta=0.53)$ is the factor that has most impact on employee satisfaction, and it is followed by the factor Salary and Remuneration Policy $(\beta=0.276)$.

Table 11. Coefficients

\begin{tabular}{|c|c|c|c|c|}
\hline \multirow{2}{*}{ Models } & \multicolumn{2}{|c|}{ Un-standardized Coefficients } & \multirow{2}{*}{$\mathrm{t}$} & \multirow{2}{*}{ Sig } \\
\hline & B & Std. Error & & \\
\hline Constant & 619 & .209 & 2.955 & .004 \\
\hline Workplace Environment Characteristics & .021 & .011 & 1.873 & .063 \\
\hline Salary and Remuneration Policy & .031 & .012 & 2.514 & .013 \\
\hline Supervisor Support & .031 & .023 & 1.338 & .183 \\
\hline Performance Appraisal Process & .053 & .011 & 4.651 & .000 \\
\hline Recruitment Process & -.009 & .014 & -.642 & .522 \\
\hline Professional Development and Training & .014 & .020 & 691 & .491 \\
\hline
\end{tabular}

\section{Main Findings and Contributions}

This study, firstly, attempts to apply an effective model of job satisfaction (1) to measure employees' satisfaction towards the job aspects in two kinds of enterprises (state-owned enterprises and foreign-owned enterprises) and (2) to make a comparison between the satisfaction levels of these employees.

This study has not only provided an effective methodology for testing measurement scale of job satisfaction, but it has also contributed by providing and testing a model with 06 job aspects: (1) workplace environment characteristics, (2) salary and remuneration policy, (3)supervisor support, (4) performance appraisal process, (5) recruitment process and (6) professional development and training.

Although the study has some limitations, its' significant findings may help the enterprise to find effective strategies for improving the level of satisfaction of the employee. Managers must realize that huge profits are easily gotten from taking care of the key factors that have most impact on staff's satisfaction. Moreover, to effectively develop these factors, the managers have to motivate and encourage their staff how to show their ability at workplace.

For the state-owned enterprise, as the results of the current study, recruitment process is the most important factor that helps to improve the satisfaction of employee. Recruitment process may vary, but normally the managers must let it carry out through nine steps: (1) Job order; (2) Identifying candidates; (3) Interview of candidates; (4) References and Checks; (5) CV presentation for clients; (6) Interview preparation; (7) Follow up after interview; (8) Salary negotiation; (9) Signing of contract. Besides, to maintain the image and reputation of the company, the recruitment process must be kept in fairness and excellence in all stages of the recruitment process. 
For the foreign-owned enterprise, as the results of the current study, Performance Appraisal Process is the most important factor that helps to improve the satisfaction of employee. A performance appraisal is a formal interaction between employees and the manager, so the boss should keep it effectively. Managers should ensure the performance of the employee is assessed and discussed in thorough detail, with communicating the weaknesses and strengths observed in the employee and also identifying opportunities for the employee to develop professionally. The employees should be informed and the standards of their performance should be clearly explained. This will help them to understand their roles and to know what exactly is expected from them.

\section{Limitations and Future Researches}

As in studies, this research is not without limitations and gaps. However, considering the positive aspects, the limitations in this study may help future similar research to have a complete and comprehensive result.

Firstly, this survey is limited because it investigates the situation of restricted amount of respondents. The research is limited in surveyed respondents, so that the ability to apply the research results to other geographic areas is difficult because of the difference of employee' psychology and expectation.

Second, this study focused only on factors which directly impact employee satisfaction without consideration of the impact of the intermediate elements, such as employee's behavior and loyalty, conducting a research at family business or private companies.

Third, this study only focused on six basic factors at general level. Other studies could focus more in details. For example, labor safety, colleague interaction, welfare, etc.

\section{References}

Birkinshaw, J., \& Hood, N. (1998). Multinational subsidiary evolution: Capability and charter change in foreign-owned subsidiary companies. Academy of management review, 23(4), 773-795. http://dx.doi.org/10.5465/AMR.1998.1255638

Bockerman, P., \& Ilmakunnas, P. (2009). Unemployment and self - assessed health: Evidence from panel data. Health economics, 18(2), 161-179. http://dx.doi.org/10.1002/hec.1361

Cascio, W. F., \& McEvoy, G. (1992). Managing human resources: Productivity, quality of work life, profits (Vol. 2). McGraw-Hill.

Coomber, B., \& Louise Barriball, K. (2007). Impact of job satisfaction components on intent to leave and turnover for hospital-based nurses: a review of the research literature. International journal of nursing studies, 44(2), 297-314. http://dx.doi.org/10.1016/j.ijnurstu.2006.02.004

DeShields Jr, O. W., Kara, A., \& Kaynak, E. (2005). Determinants of business student satisfaction and retention in higher education: applying Herzberg's two-factor theory. International journal of educational management, 19(2), 128-139. http://dx.doi.org/10.1016/j.jinurstu.2008.06.009

Edgington, D. W., \& Hayter, R. (2001). Japanese direct foreign investment and the Asian financial crisis. Geoforum, 32(1), 103-120.

Golbasi, Z., Kelleci, M., \& Dogan, S. (2008). Relationships between coping strategies, individual characteristics and job satisfaction in a sample of hospital nurses: cross-sectional questionnaire survey. International Journal of Nursing Studies, 45(12), 1800-1806.

Gyekye, S. A., \& Salminen, S. (2009). Educational status and organizational safety climate: Does educational attainment influence workers' perceptions of workplace safety?. Safety science, 47(1), 20-28. http://dx.doi.org/10.1016/j.ssci.2007.12.007

Janssen, O., \& Van Yperen, N. W. (2004). Employees' goal orientations, the quality of leader-member exchange, and the outcomes of job performance and job satisfaction. Academy of management journal, 47(3), 368-384. http://dx.doi.org/10.2307/20159587

Kaliski, B.S. (2007). Encyclopedia of Business and Finance (Second ed.). Thompson Gale, Detroit, p. 446.

Kumaran, R. I., Thakar, R., \& Spector, D. L. (2008). Chromatin dynamics and gene positioning. Cell, 132(6), 929-934. http://dx.doi.org/10.1016/j.cell.2008.03.004

Maslach, C., Schaufeli, W. B., \& Leiter, M. P. (2001). Job burnout. Annual review of psychology, 52(1), 397-422. http://dx.doi.org/10.1146/annurev.psych.52.1.397 
Nemeth, E., Tuttle, M. S., Powelson, J., Vaughn, M. B., Donovan, A., Ward, D. M., ... \& Kaplan, J. (2004). Hepcidin regulates cellular iron efflux by binding to ferroportin and inducing its internalization. Science, 306(5704), 2090-2093. http://dx.doi.org/10.1126/science.1104742

Nguyen, N. T., Tran, T. T., \& Wang, C. N. (2014). An Empirical Study of Customer Satisfaction towards Bank Payment Card Service Quality in Ho Chi Minh Banking Branches. International Journal of Economics and Finance, 6(5), 170-181. http://dx.doi.org/10.5539/ijef.v6n5p170

Nilan, P. (1999). Young people and globalizing trends in Vietnam. Journal of Youth Studies, 2(3), 353-370. http://dx.doi.org/10.1080/13676261.1999.10593047

Randolph, D. S. (2004). Predicting the effect of extrinsic and intrinsic job satisfaction factors on recruitment and retention of rehabilitation professionals. Journal of healthcare management/American College of Healthcare Executives, 50(1), 49-60.

Sekar, R., Bendre, M., Dhurjati, D., \& Bollineni, P. (2001). A fast automaton-based method for detecting anomalous program behaviors. In Security and Privacy, 2001. S\&P 2001. Proceedings. 2001 IEEE Symposium on (pp. 144-155). IEEE.

Spector, P. (1997). Job Satisfaction: Application, Assessment, Causes and Consequences. California: Sage.

Tsang, E. W., Nguyen, D. T., \& Erramilli, M. K. (2004). Knowledge acquisition and performance of international joint ventures in the transition economy of Vietnam. Journal of International Marketing, 12(2), 82-103. http://dx.doi.org/10.1509/jimk.12.2.82.32901

Wang, C. N., Nguyen, N. T., \& Tran, T. T. (2014). The Study of Staff Satisfaction in Consulting Center System-A Case Study of Job Consulting Centers in Ho Chi Minh City, Vietnam. Asian Economic and Financial Review, $4(4), 472-491$.

Wang, L. W., Tran, T. T., \& Nguyen, N. T. (2014). Analyzing Factors to Improve Service Quality of Local Specialties Restaurants: A Comparison with Fast Food Restaurants in Southern Vietnam. Asian Economic and Financial Review, 4(11), 1592-1606.

Wright, P. M., Dunford, B. B., \& Snell, S. A. (2001). Human resources and the resource based view of the firm. Journal of management, 27(6), 701-721. http://dx.doi.org/10.1177/014920630102700607 